\title{
Physicochemical characterization and quantification of bioactive compounds of guava powder produced by cast-tape drying
}

\author{
Ana Caroline FRABETTI ${ }^{1 *}$ (D), Angelise DURIGON ${ }^{2}$, João LAURINDO ${ }^{1}$, Jaqueline Oliveira de MORAES ${ }^{1}$, \\ Bruno CARCIOFI ${ }^{1}$
}

\begin{abstract}
Guava (Psidium guajava L.) is one of the most nutritious fruits from tropical and subtropical regions; however, it is a seasonal and easily perishable fruit, besides not being produced worldwide. In this context, dehydration to produce powders simplifies product transportation and storage, however, the knowledge of bioactive compounds after drying is extremely important. Guava was dehydrated by a pilot scale cast-tape drying (CTD), a new low-cost dryer that allows the control of the spreading thickness, reducing significantly the drying time. Guava pulp was spread in CTD using 2 and $3 \mathrm{~mm}$ and dried at $98^{\circ} \mathrm{C}$ to obtain powders with moisture contents of about $0.04 \mathrm{~g} / \mathrm{g}$ (dry basis) and water activities close to 0.30 . Powders obtained by CTD were compared to powders dried by freeze-drying (FD), and both drying processes, as well as guava pulp, showed high antioxidant activity and significant values of carotenoids and phenolic contents. Guava powders exhibited a wide range of particle sizes and flake-like structures, being easily dispersed in water, which indicates good rehydration properties of the products obtained from both drying methods. Therefore, CTD is a suitable process to produce guava powders with attractive properties, proving the preservation of important nutritional characteristics of the fruit.
\end{abstract}

Keywords: guava; drying; powder; carotenoids; phenolic; antioxidant.

Practical applications: This study investigated properties of guava powder obtained by CTD, proving that the process promoted easy dispersion in water, a structure comparable to freeze dried powders and maintained significant values of nutrients. These are important results because they show that a quality dry food can be produced with CTD, in less time and costing less than freeze drying. In addition, the fruit drying allows its consumption worldwide, even in countries where some types of fruits are not produced.

\section{Introduction}

Guava (Psidium guajava L.) is a nutritious and appealing fruit from tropical and subtropical regions. Guava is tasty, with a pleasant and intense flavor, has low caloric value $(68 \mathrm{kcal} / 100 \mathrm{~g})$ besides being a good source of phenolic compounds, such as carotenoids (cryptoxanthin, lycopene, and b-carotene) and vitamin C (U.S. Department of Agriculture, 2015). However, the fruit is perishable with a short shelf-life because of its intense metabolic activity after harvesting, which limits transportation and storage period (Silva et al., 2018). In the interest of increasing the usage and add value to guava fruit, drying to produce powder is an alternative to increase its shelf life and usage by industry, as a business-to-business product (Cuq et al., 2011; Nunes et al., 2016). To develop powders with desirable functional properties that can be applied in the food industry, much attention has been paid to the understanding of powder properties, like chemical composition, packed bed porosity, size, form, density, and stability (Argyropoulos et al., 2011; Cuq et al., 2011; Kurozawa et al., 2012; López-Córdoba \& Goyanes, 2017; Zhang et al., 2006).
Cast-tape drying (CTD) has been reported as a competitive drying technology, able to produce dry powders that are compared to those produced by freeze-drying (Abonyi et al., 2002; Caparino et al., 2012; Durigon et al., 2016; Nindo et al., 2007; Pavan et al., 2012). The process consists in spreading the solution to be dried over a flexible film while its lower surface is in contact with hot water or steam, which provides the heat for the drying process. An advantage of this method is the possibility of using moderate drying temperatures $\left(60-80^{\circ} \mathrm{C}\right)$ and relatively short times (some minutes) by selecting the appropriate thickness of the pulp layer to be dried (Zotarelli et al., 2017).

Previous studies investigated the influence of pulp thickness and support type (polyester film - Mylar - and fiberglass coated with Teflon') on the drying rates of fruit pulps dried by CTD. Dehydration of guava pulp by cast-tape drying has a constantrate period, with high drying rate and evaporative capacity, mainly when a thin pulp layer is applied. The type of support did not influence the drying rates, but guava pulp was less sticking to the surface of Teflon-based support, which is vital 
for industrial applications (Frabetti et al., 2018). Lower product thickness resulted in higher drying rates and shorter drying times, which may have an impact on the powder nutritional quality (Durigon et al., 2017; Ochoa-Martínez et al., 2012; Ocoró-Zamora \& Ayala-Aponte, 2013; Zotarelli et al., 2015).

The goal of this study was to compare the physicochemical properties of guava powders produced by CTD and by freezedrying.

\section{Material and methods}

\subsection{Guava pulp}

Commercial guava pulp was purchased from the local market

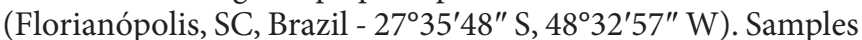
presented soluble solids between 5.0 and $6.6^{\circ} \mathrm{Brix}$, determined with a manual refractometer (ATAGO, model PAL-BX/RI, Tokyo, Japan). The moisture content, on a dry basis $(X)$, ranged from 8.2 to $10.4 \mathrm{~g} / \mathrm{g}$, determined by the gravimetric method under vacuum (TECNAL Vacuum oven, model TE-395, Brazil) at $70{ }^{\circ} \mathrm{C}$ (Association of Official Analytical Chemists, 2012). Guava pieces were crushed in a blender (Arno, São Paulo, SP, Brazil) for 1 min and sifted in a 16-mesh sieve to produce the pulp to be dried.

\subsection{Cast-tape drying (CTD): experimental device and operational procedures}

The cast-tape drying (CTD) employed for drying procedures is exhibited in Figure 1. The equipment and methods are also discussed by Frabetti et al. (2018). CTD uses steam as heating media, which is in contact with the bottom surface of a $0.25-\mathrm{mm}$ thick fiberglass fabric with $59 \%$ of polytetrafluoroethylene -Teflon (Indaco, Sheet Armalon Standard, São Paulo, Brazil), which is the flexible support where the guava pulp was spread.

CTD has a reservoir made of stainless steel $(0.80 \mathrm{~m} \times 0.40 \mathrm{~m} \times 0.20 \mathrm{~m})$, partially filled with water and a pump (KOMECO, model TP 40 G3, Palhoça, SC, Brazil) promotes the circulation of hot water $\left(98 \pm 1{ }^{\circ} \mathrm{C}\right)$ into the reservoir. Two resistors are responsible for the water heating to produce vapor that fills the space between the water surface and the bottom surface of the flexible support. Pt100 sensors

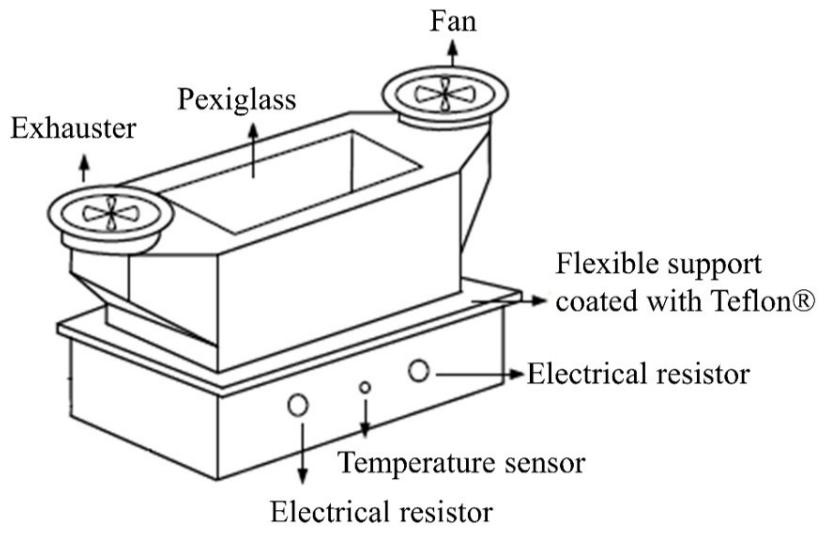

Figure 1. Schematic of cast-tape drying equipment.
(Alutal ${ }^{\circ}$ Controles Industrial, TRS12, Votorantim, SP, Brazil) controlled the temperature of the water. A fan and an exhauster were installed above the flexible support (Qualitas Indústria Eletromecânica Ltda, FAQ8, Itapira, SP, Brazil) to remove the evaporated water from the pulp. The volumetric flow rate of the carrying air was $198.07 \pm 51.65 \mathrm{~m}^{3} \mathrm{~h}^{-1}$.

To perform the experiences, as previously described by Frabetti et al. (2018), water contained in the CTD reservoir was pre-heated until $98^{\circ} \mathrm{C}$ and then the guava pulp was spread on the flexible support (fiberglass-Teflon fabric) using a doctorblade (Tape Casting Warehouse, model Doctor Blade Assembly, Morrisville, PA, USA). Thicknesses of $2 \mathrm{~mm}$ or $3 \mathrm{~mm}$ thickness were chosen. Drying was performed in triplicate with an inlet air temperature of $21.0 \pm 5.0^{\circ} \mathrm{C}$ and relative humidity in the range of $65-75 \%$, measured by a thermo-hygrometer (Testo, model 610, Lenzkirch, Baden-Württemberg, German). A thermoanemometer (Testo, model 425, Lenzkirch, German) recorded the air velocities during drying (data not shown). The instrument was placed $2 \mathrm{~cm}$ above the support with pulp spreading and at four different positions.

\subsection{Freeze-drying}

Guava pulp was frozen at $-60^{\circ} \mathrm{C}$ for $12 \mathrm{~h}$ and then dehydrated in a freeze dryer (Liotop L101, Liobrás, São Carlos, Brazil) for $48 \mathrm{~h}$ and $0.02 \mathrm{kPa}$.

\subsection{Milling and classification}

At the end of the drying process, when the pulp reached approximately $3 \%$ of moisture (wet basis), guava flakes resulting from CTD were subjected to milling in a knife mill (TECNAL, TE 631/2, Brazil) for approximately $40 \mathrm{~s}$ at $19500 \mathrm{rpm}$, and later classified into consecutive 20 and 25 mesh sieves. The same procedure was applied to the freeze-dried pulp.

\subsection{Physicochemical characterization of fresh guava and powder samples}

Color and chemical analysis (antioxidant activity, phenolic, and carotenoids content) of guava pulp and powders produced by CTD and freeze-drying were carried out. The results allowed evaluating the effects of both drying methods on the guava pulp.

\subsection{Moisture content and water activity}

The moisture content of powder samples was determined by the gravimetric method, under vacuum, at $70{ }^{\circ} \mathrm{C}$ according to Association of Official Analytical Chemists (2012). Water activity $\left(a_{\mathrm{w}}\right)$ was determined with a digital hygrometer (Aqualab, Decagon Devices, USA). Analyzes were performed in triplicate.

\subsection{Powder dispersion time}

Particle size distribution was determined by laser diffraction using a particle size analyzer (Mastersizer, Mastersizer 2000, Malvern Instruments, UK). Samples were dispersed in ethanol (99.5\%), and De Brouckere mean diameter (D $[4,3]$ ), in $\mu \mathrm{m}$, 
which indicates the size of particles constituting most of the sample volume, was determined according to Equation 1:

$$
\mathrm{D}[4,3]=\frac{\sum_{\mathrm{i}=1}^{\mathrm{n}} \mathrm{n}_{\mathrm{i}} \mathrm{d}_{\mathrm{i}}^{4}}{\sum_{\mathrm{i}=1}^{\mathrm{n}} \mathrm{n}_{\mathrm{i}} \mathrm{d}_{\mathrm{i}}^{3}}
$$

\subsection{Bulk density, particle density, and porosity}

Bulk density $\left(\rho_{B}\right)$ of the powders was determined as reported by Barbosa-Cánovas et al. (2005). The real volume of particles was determined in a gas pycnometer using helium (Micromeritics, AccuPyc II 1340, USA). The particle density $\left(\rho_{P}\right)$ was calculated from the ratio between sample mass and particles volume, expressed in $\mathrm{g} / \mathrm{cm}^{3}$.

The particles bed porosity $(\varepsilon)$ was calculated according to Equation 2:

$$
\varepsilon=\frac{\rho_{\mathrm{P}}-\rho_{\mathrm{B}}}{\rho_{\mathrm{P}}}
$$

\subsection{Color}

The color parameters of the powders were determined in triplicate by with a colorimeter (Minolta Chroma Meter CR-400, Konica Minolta, Osaka, Japan) using CIELAB scale and through parameters $\mathrm{a}^{\star}\left(+\mathrm{a}^{*}=\right.$ red, $-\mathrm{a}^{\star}=$ green $), \mathrm{b}^{*}$ $\left(+b^{\star}=\right.$ yellow; $-b^{*}=$ blue $)$ and $L^{\star}\left(L^{\star}=0\right.$ : black; $L^{\star}=100$ : white $)$.

\subsection{Scanning electron microscopy}

Scanning electron microscopy (JEOL, Model JSM-6390LV, U.S.A.) was used to evaluate powder microstructure. The samples were coated with gold before the analysis using a metallizer (LEICA, model SCD 500, Buffalo Grove, IL, USA). The samples were examined using an accelerating voltage of $10 \mathrm{kV}$ and magnification of $100 \mathrm{x}$.

\subsection{Extracts preparation}

An extractive solution based on methanol/water/formic acid (50: 48.5: 1.5) was prepared. Subsequently, $25 \mathrm{~mL}$ of this solution was added to $0.5 \mathrm{~g}$ of sample (powder or pulp). For guava pulp, the mass equivalent to $0.5 \mathrm{~g}$ of powder was calculated considering $7 \%(\mathrm{w} / \mathrm{v})$ product's solids content; this extract was used in the analyzes described in the following.

\subsection{Antioxidant activity}

\section{The capture of ABTS free radical}

A stock solution of $7 \mathrm{mM}$ 2,2'-azino-bis-(3-ethylbenzothiazoline6-sulfonic acid) diammonium salt (ABTS) in $2.45 \mathrm{mM}$ potassium persulfate was prepared and stored in a dark place at room temperature for $12-16 \mathrm{~h}$, as described by Re et al. (1999). Then, $3 \mathrm{~mL}$ of the diluted ABTS solution was added in $30 \mu \mathrm{L}$ of extract and kept in the dark at $30^{\circ} \mathrm{C}$ for $25 \mathrm{~min}$. The spectrophotometer (FEMTO, Model 800XI,
São Paulo, Brazil) was calibrated with ethanol solution (control), and radical scavenging ability was calculated by Equation 3 :

$\operatorname{Inhibition}(\%)=\left(\frac{\mathrm{A}_{\mathrm{bs}(\text { control })}-\mathrm{A}_{\mathrm{bs}(\text { sample })}}{\mathrm{A}_{\mathrm{bs}(\mathrm{control})}}\right) \times 100$

where $\mathrm{A}_{\mathrm{bs} \text { (control) }}$ and $\mathrm{A}_{\mathrm{bs} \text { (sample) }}$ are the absorbances read for the control solution and the samples with extract, respectively. Results were expressed in $\mu \mathrm{M}$ of Trolox equivalents per gram of dry sample.

\section{Capture of DPPH free radical}

Antioxidant activity was also determined by free radical capture of 2,2-diphenyl-1-picrylhydrazyl (DPPH), based on the methodology described by Brand-Williams et al. (1995). Aliquots of $100 \mu \mathrm{L}$ of extract solutions were added to $3.9 \mathrm{~mL} \mathrm{DPPH} 6 \times 10$ ${ }^{5} \mathrm{M}$ methanolic solution under vortexing, according to Tonon et al. (2009). After $60 \mathrm{~min}$ reaction protected from light and at room temperature, the absorbance of samples was read in a spectrophotometer (HACH, Model DR 5000, Germany), at $515 \mathrm{~nm}$ wavelength. Results were expressed in $\mu \mathrm{M}$ of Trolox equivalents per gram of dry sample.

\subsection{Total phenol content (TPC)}

TPC was determined according to the modified Folin-Ciocalteu method described by Singleton et al. (1999). The absorbances were read in a spectrophotometer (FEMTO, Model 800XI, São Paulo, Brazil) at $760 \mathrm{~nm}$ wavelength. The results were expressed in $\mathrm{mg}$ of gallic acid equivalent (GAE) per $100 \mathrm{~g}$ of dry sample.

\subsection{Total carotenoids (TC)}

TC content was determined following the methodology described by Rodriguez-Amaya (2001). The experiments were carried out under light protection. The absorbance was measured in a spectrophotometer (FEMTO, Model 800XI, São Paulo, Brazil) with a wavelength of $472 \mathrm{~nm}$, using petroleum ether as control.

TC content, given by Equation 4, was expressed as equivalent of lycopene ( $\mu \mathrm{g} / \mathrm{g} \mathrm{d}$. w.), that is the carotenoid compound most found in guavas, being $86 \%$ of the total carotenoid content (Padula \& Rodriguez-Amaya, 1986):

$\mathrm{TC}=\frac{\mathrm{V}_{\mathrm{d}} \times \mathrm{A}_{\mathrm{bs}} \times 10^{4}}{\mathrm{E}_{1}^{1 \%} \mathrm{~cm} \times \mathrm{m}_{1}}$

where $V_{d}$ is the dilution volume $(\mathrm{mL}), A_{b s}$ is the absorbance, $\mathrm{E}_{1}^{1 \% \mathrm{~cm}}$ is the extinction coefficient of lycopene in petroleum ether (3450, according to Choudhari \& Ananthanarayan, 2007) and $\mathrm{m}_{1}$ is the samples dry weight $(\mathrm{g})$.

\subsection{Statistical analysis}

A multiple comparison of average values was performed with One-way ANOVA and Tukey's test at 90\% confidence level $(\mathrm{p}<0.10)$, using software Statistica 8.0 (Statsoft Inc., Tulsa, OK, USA). 


\section{Results and discussion}

\subsection{Moisture content and water activity}

Table 1 shows the values of moisture content and water activity of guava powders produced by CTD and freeze-drying.

All the samples presented values of water activity lower or close to 0.3, indicating microbiological stability (Labuza, 1980; Rahman, 2007). The higher water activity of the freeze-dried sample is explained from its higher moisture content. The moisture content of guava powder produced by cast-tape drying was $0.04 \mathrm{~g} / \mathrm{g}$, which depends on the drying time and the air conditions (temperature and relative humidity). Other studies on CTD of fruits, like tomatoes, mango, and papaya puree, reported similar results of moisture and water activity for the resulting powders (Caparino et al., 2012; Castoldi et al., 2015; Durigon et al., 2016; Ocoró-Zamora \& Ayala-Aponte, 2013; Zotarelli et al., 2017).

The shelf life of food powders can be shortened by physical changes and chemical reactions during storage. For these foods, both changes are controlled by the state of the water in the food (Bhandari et al., 2013). The very low water activities observed in guava powders produced by CTD favors powders' stability.

\subsection{Dispersion time}

Dispersion times found for powders are shown in Table 2.

Guava powders produced by CTD showed very low dispersion times (around $3 \mathrm{~s}$ ), while freeze-dried powder

Table 1. Moisture content and water activity of guava powders.

\begin{tabular}{cccc}
\hline Process & $\begin{array}{c}\text { Pulp thickness } \\
(\mathrm{mm})\end{array}$ & $\begin{array}{c}\text { Moisture content } \\
(\mathrm{g} / \mathrm{g} \text { dry basis })\end{array}$ & Water activity \\
\hline CTD & 2 & $0.03 \pm 0.00^{\mathrm{a}}$ & $0.23 \pm 0.01^{\mathrm{b}}$ \\
& 3 & $0.03 \pm 0.00^{\mathrm{a}}$ & $0.24 \pm 0.01^{\mathrm{b}}$ \\
Freeze-drying & - & $0.04 \pm 0.00^{\mathrm{a}}$ & $0.33 \pm 0.02^{\mathrm{a}}$ \\
\hline
\end{tabular}

${ }^{a-b}$ Means with the same superscript letters within a column indicate no significant differences $(\mathrm{p}<0.10)$

Table 2. Dispersion time of guava powders.

\begin{tabular}{ccc}
\hline Process & Pulp thickness $(\mathrm{mm})$ & Dispersion time $(\mathrm{s})$ \\
\hline CTD & 2 & $3.14 \pm 0.27^{\mathrm{b}}$ \\
& 3 & $3.25 \pm 0.3^{2 \mathrm{~b}}$ \\
Freeze-drying & - & $9.03 \pm 0.46^{\mathrm{a}}$ \\
\hline
\end{tabular}

${ }^{a-b}$ Means with the same superscript letters within a column indicate no significant differences $(\mathrm{p}<0.10)$. presented a higher time for complete dispersion (approximately 9 s). Durigon et al. (2016) reported dispersion times around $17 \mathrm{~s}$ for CTD tomato powder and $30 \mathrm{~s}$ for freeze-dried powder. Dispersion time is directly related to the powder wettability, linked to the susceptibility of porous particles to be penetrated by water, that depends on both the chemical composition and physical factors, as size, shape and surface area of the particles, as well as on the water temperature. A good parameter is that $90 \%$ of the powder immerses in the liquid in up to $5 \mathrm{~min}$ (Lannes \& Medeiros, 2003; Tonon et al., 2009).

\subsection{Bulk density, particle density, porosity, and particle size distribution}

Bulk density, particle density, porosity and the mean diameter of guava powders are shown in Table 3.

Guava powders had a bulk density between $0.3-0.8 \mathrm{~g} / \mathrm{cm}^{3}$ and a particle density of about $1.5 \mathrm{~g} / \mathrm{cm}^{3}$. Mahendran (2010) studied guava powders produced by freeze-drying, reporting a bulk density of $0.65 \mathrm{~g} / \mathrm{cm}^{3}$ and particle density of $1.71 \mathrm{~g} / \mathrm{cm}^{3}$. As reported by other authors, CTD powders present higher bulk densities and lower porosity values, when compared to powders produced by freeze-drying and spray drying (Caparino et al., 2013; Durigon et al., 2016; Zotarelli et al., 2017).

Powders from CTD and freeze-drying presented a wide range of particle size, after the same grinding process, using a knife mill, and sifting. Particle sizes CTD and freeze-drying powders, after milling, ranged from 5.75 to $2187 \mu \mathrm{m}$ and from 11.48 to $2187 \mu \mathrm{m}$, respectively. These values are similar to those reported by Durigon et al. (2016) and Castoldi et al. (2015) for tomato powders produced by the same drying-milling technique, indicating that the milling process controls the particle size distribution. The mean diameter of the particles (Table 3), expressed as D [4,3] (De Brouckere mean diameter), varied between $365.10 \pm 31.35 \mu \mathrm{m}$ and $483.35 \pm 16.97 \mu \mathrm{m}$.

\subsection{Scanning electron micrographs}

Figure 2 shows the images obtained by scanning electron micrographs (SEM). Guava powders produced by CTD and freeze-drying exhibited flake-like structures, with irregular size and shape. The same was noticed by Durigon et al. (2016) for tomato powders, as well as by Caparino et al. (2012) and by Zotarelli et al. (2017) for mango powders. Freeze-dried powders showed irregular surface, related to their higher porosity, created by the ice sublimation.

Table 3. Mean diameter, bulk density, particle density and porosity of guava powders.

\begin{tabular}{cccccc}
\hline \multirow{2}{*}{ Process } & Pulp thickness $(\mathrm{mm})$ & $\begin{array}{c}\text { Mean diameter D [4,3] } \\
(\mu \mathrm{m})\end{array}$ & Bulk density $\left(\mathrm{g} / \mathrm{cm}^{3}\right)$ & Particle density $\left(\mathrm{g} / \mathrm{cm}^{3}\right)$ & Porosity $(\%)$ \\
\hline CTD & 2 & $483.35 \pm 16.97^{\mathrm{a}}$ & $0.75 \pm 0.01^{\mathrm{b}}$ & $1.49 \pm 0.00^{\mathrm{a}}$ & 50 \\
& 3 & $365.10 \pm 31.35^{\mathrm{b}}$ & $0.78 \pm 0.00^{\mathrm{a}}$ & $1.50 \pm 0.00^{\mathrm{a}}$ & 48 \\
Freeze drying & - & $371.98 \pm 36.93^{\mathrm{b}}$ & $0.28 \pm 0.01^{\mathrm{c}}$ & $1.47 \pm 0.00^{\mathrm{a}}$ & 81 \\
\hline
\end{tabular}

${ }^{a-c}$ Means with the same superscript letters within a column indicate no significant differences $(p<0.10)$. 

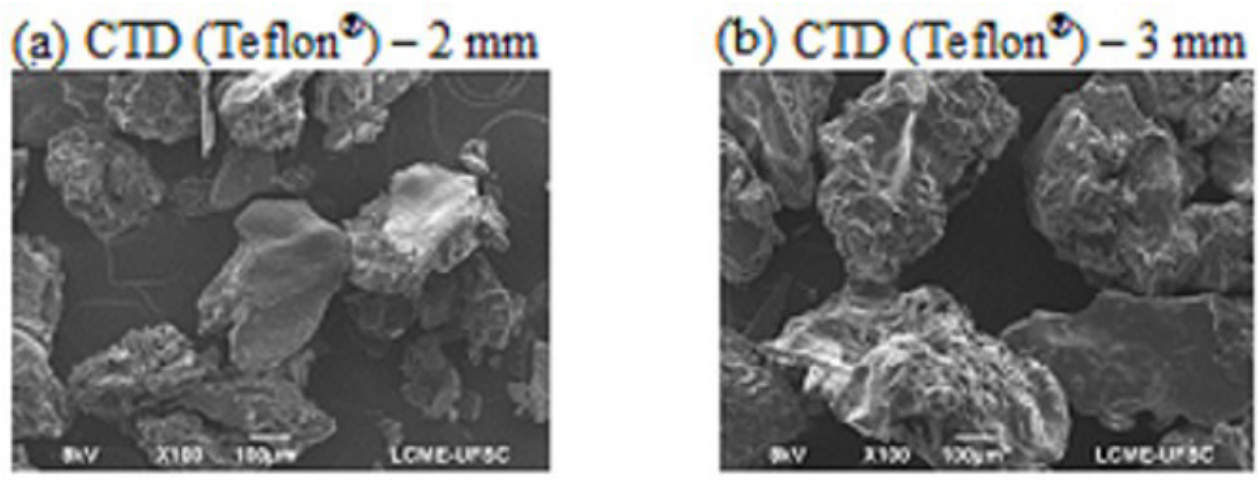

(c) Freeze-drying

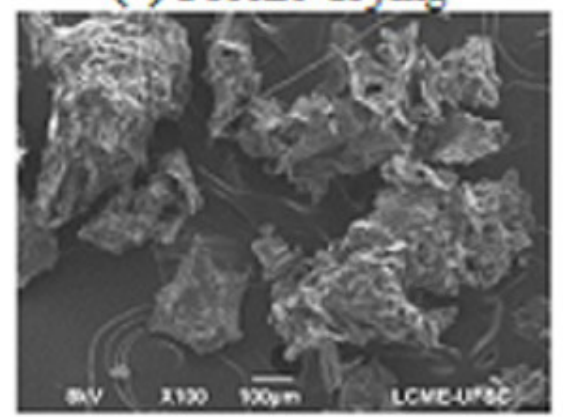

Figure 2. Scanning electron microscopy (SEM) images (100x) of guava powders produced by: (a) CTD - 2 mm; (b) CTD - 3 mm; (c) Freeze-drying.

\subsection{Color}

Color parameters are shown in Table 4.

The luminosity values $\left(\mathrm{L}^{*}\right)$ for CTD powders were lower than those found from freeze-dried powder. CTD powder presented higher values of $\mathrm{a}^{*}$ and $\mathrm{b}^{*}$, showing that red and yellow colors are more intense than in freeze-dried powder. The darker color of the CTD powder might be explained by a browning reaction or Maillard reaction, and by oxidation of ascorbic acid, due to the exposure to the ambient air at relatively high temperatures during drying.

The current color of guava pulp is red, and thus the positive parameter $\mathrm{a}^{\star}$ is important to identify color changes during drying. A small difference between the $\mathrm{a}^{*}$ values of CTD and freeze-dried powders and the raw material indicate that both processes do not change a lot the characteristic guava redness. The positive values of the parameters $\mathrm{a}^{\star}$ and $\mathrm{b}^{\star}$ also suggest preservation of carotenoids.

\subsection{Antioxidant activity, carotenoids, and phenolic contents}

Results of antioxidant activity using ABTS and DPPH, as well as the contents of carotenoids and phenolic compounds in the samples, are shown in Table 5.

Antioxidant activities from ABTS and DPPH methods were very similar for powders and guava pulp. This unexpected result may have been influenced by the different extraction yield from powders and guava pulp, which tends to be higher from powders. The grinding process may have destroyed the remnant fruit cells, easing the extraction of the compounds from the intra-cellular spaces (Naczk \& Shahidi, 2004; Pereira \& Meireles, 2010).
One major limitation of the spectrophotometric method used for ABTS and DPPH analysis is the overlapped spectra of compounds that absorb light in the same wavelength range. For example, anthocyanins have strong absorption on the same wavelength range $(500-550 \mathrm{~nm})$ as $\mathrm{DPPH}$. Thus, they may introduce interference with the results and their interpretation (Zhong \& Shahidi, 2015).

As observed in Table 5, TPC obtained for pulp and powders samples was high. Verma et al. (2015) studied the effect of various dehydration techniques on the physicochemical and nutritional properties of guava powder and obtained overestimated phenolic data, of 20,300 mg of gallic acid equivalent/100 g (d.w.) for freeze-dried guava powder. Likewise working with guava and using Folin-Ciocalteu method, Kubola et al. (2011) reported value of $1080 \mathrm{mg}$ of gallic acid equivalent/100 g (d.w.), while Silva et al. (2014) reported $1723 \mathrm{mg}$ of gallic acid equivalent /100 g (d.w.), both for fresh fruits. These authors justified that, at the cellular level, the phenolic compounds are in the vacuoles and are separated from oxidative enzymes in intact fruits. This structure collapses during drying, leading to a release of more phenolic compounds, together with the oxidative and hydrolytic enzymes that may degrade the phenolic compounds. Also, overestimation of TPC is a major concern for the Folin-Ciocalteu assay, due to the contribution of non-phenolic reducing agents, such as reducing sugars and certain amino acids, present in the system to the reduction of the reagent (Zhong \& Shahidi, 2015).

Carotenoids content in guava pulp and powders are presented in Table 5 as lycopene equivalent $(\mu \mathrm{g} / \mathrm{g}$ d.w.). The highest value was found for guava pulp, followed by freeze-dried powder. In this study, guava pulp presented 
Table 4. Color parameters of guava powders.

\begin{tabular}{ccccc}
\hline Samples & Pulp thickness $(\mathrm{mm})$ & $\mathrm{L}^{*}$ & $\mathrm{a}^{\star}$ & $\mathrm{b}^{*}$ \\
\hline CTD & 2 & $49.77 \pm 1.11^{\mathrm{c}}$ & $34.86 \pm 0.53^{\mathrm{a}}$ & $31.62 \pm 0.86^{\mathrm{a}}$ \\
& 3 & $52.76 \pm 0.18^{\mathrm{b}}$ & $32.22 \pm 0.11^{\mathrm{b}}$ & $31.75 \pm 0.19^{\mathrm{a}}$ \\
Freeze-drying & - & $63.20 \pm 0.52^{\mathrm{a}}$ & $27.25 \pm 0.38^{\mathrm{c}}$ & $28.31 \pm 0.16^{\mathrm{b}}$ \\
\hline
\end{tabular}

${ }^{a-c}$ Means with the same superscript letters within a column indicate no significant differences $(\mathrm{p}<0.10)$.

Table 5. Chemical analyzes performed on guava pulp and powders.

\begin{tabular}{|c|c|c|c|c|c|}
\hline \multirow{2}{*}{ Samples } & \multirow{2}{*}{ Pulp thickness (mm) } & \multicolumn{2}{|c|}{ Antioxidant activity ( $\mu \mathrm{m}$ Trolox/g d.w.) } & \multirow{2}{*}{$\begin{array}{l}\text { Carotenoid content } \\
(\mu \mathrm{g} / \mathrm{g} \text { d.w. })\end{array}$} & \multirow{2}{*}{$\begin{array}{c}\text { TPC } \\
\text { (mg GAE/100 g d.w.) }\end{array}$} \\
\hline & & ABTS & $\mathrm{DPPH}$ & & \\
\hline Guava pulp & - & $1867.16 \pm 8.14^{\mathrm{a}}$ & $9429.38 \pm 3158.82^{\mathrm{a}}$ & $291.67 \pm 10.39^{\mathrm{a}}$ & $1361.28 \pm 72.76^{\mathrm{a}}$ \\
\hline \multirow[t]{2}{*}{ CTD } & 2 & $1870.31 \pm 0.44^{\mathrm{a}}$ & $7652.19 \pm 1204.56^{\mathrm{a}}$ & $173.88 \pm 4.51^{\mathrm{b}}$ & $1341.19 \pm 9.68^{\mathrm{a}}$ \\
\hline & 3 & $1861.13 \pm 20.47^{\mathrm{a}}$ & $7504.40 \pm 988.41^{\mathrm{a}}$ & $183.85 \pm 4.28^{\mathrm{b}}$ & $1324.11 \pm 92.66^{\mathrm{a}}$ \\
\hline Freeze-drying & - & $1745.36 \pm 5.65^{\mathrm{b}}$ & $7518.23 \pm 2042.52^{\mathrm{a}}$ & $251.92 \pm 9.36^{\mathrm{a}}$ & $1224.85 \pm 60.29^{\mathrm{a}}$ \\
\hline
\end{tabular}

${ }^{\mathrm{a}-\mathrm{c}}$ Means with the same superscript letters within a column indicate no significant differences $(\mathrm{p}<0.10)$.

total carotenoids of $21.66 \mu \mathrm{g} / \mathrm{g}$ (w.w.), much lower than $52.04 \mu \mathrm{g} / \mathrm{g}$ (w.w.) reported by the literature (US Department of Agriculture, 2015). Ferreira \& Rodriguez-Amaya (2008) reported $389 \mu \mathrm{g} / \mathrm{g}$ (d.w.) of lycopene in freeze-dried guava powder, which is higher than the observed in this study. However, variations in a cultivar of guava fruit, ripeness stage, and environmental factors should be considered.

\section{Conclusions}

Overall, CTD and freeze-drying allowed the production of guava powders with good physical properties, important for its stability, transport, and storage. Besides, high values of phenolic compounds and total carotenoids were achieved for both drying processes, preserving most of the nutrients present in the fruit pulp. For CTD process, the use of $2 \mathrm{~mm}$-thick or $3 \mathrm{~mm}$-thick pulp thickness did not cause relevant differences in the final products, so both can be applied to produce guava powder. The results indicate a promising success to produce guava powders with considerable levels of nutrients. Moreover, the CTD process, besides having greater energy efficiency and shorter drying times compared to freeze-drying, can be adapted to different production scales resulting in powdered fruits that can reach business-to-business companies.

\section{Conflict of interest}

The authors declare that they have no conflict of interest.

\section{Acknowledgements}

The authors thank CAPES - Brazilian Coordination for the Improvement of Higher Education Personnel for for the financial support.

\section{References}

Abonyi, B. I., Feng, H., Tang, J., Edwards, C. G., Chew, B. P., Mattinson, D. S., \& Fellman, J. K. (2002). Quality retention in strawberry and carrot purees dried with Refractance Window (TM) system. Journal of Food
Science, 67(3), 1051-1056. http://dx.doi.org/10.1111/j.1365-2621.2002. tb09452.x.

Argyropoulos, D., Heindl, A., \& Müller, J. (2011). Assessment of convection, hot-air combined with microwave-vacuum and freezedrying methods for mushrooms with regard to product quality. International Journal of Food Science \& Technology, 46(2), 333-342. http://dx.doi.org/10.1111/j.1365-2621.2010.02500.x.

Association of Official Analytical Chemists - AOAC (2012). Official methods of analysis of AOAC International (19th ed.). Gaithersburg: AOAC international.

Barbosa-Cánovas, G. V., Ortega-Rivas, E., Juliano, P., \& Yan, H. (2005). Food Powders: physical properties, processing and functionality. New York: Kluwer Academic / Plenum Publishers.

Bhandari, B., Bansal, N., Zhang, M., \& Schuck, P. (2013). Handbook of food powders (1st ed.). Cambridge: Woodhead Publishing. http:// dx.doi.org/10.1533/9780857098672.

Brand-Williams, W., Cuvelier, M. E., \& Berset, C. (1995). Use of a free radical method to evaluate antioxidant activity. LebensmittelWissenschaft + Technologie, 28(1), 25-30. http://dx.doi.org/10.1016/ S0023-6438(95)80008-5.

Caparino, O. A., Sablani, S. S., Tang, J., Syamaladevi, R. M., \& Nindo, C. I. (2013). Water sorption, glass transition, and microstructures of refractance window- and freeze-dried mango (Philippine "Carabao" Var.) powder. Drying Technology, 31(16), 1969-1978. http://dx.doi. org/10.1080/07373937.2013.805143.

Caparino, O. A., Tang, J., Nindo, C. I., Sablani, S. S., Powers, J. R., \& Fellman, J. K. (2012). Effect of drying methods on the physical properties and microstructures of mango (Philippine "Carabao" var.) powder. Journal of Food Engineering, 111(1), 135-148. http:// dx.doi.org/10.1016/j.jfoodeng.2012.01.010.

Castoldi, M., Zotarelli, M. F., Durigon, A., Carciofi, B. A. M., \& Laurindo, J. B. (2015). Production of tomato powder by refractance window drying. Drying Technology, 33(12), 1463-1473. http://dx.doi.org/1 0.1080/07373937.2014.989327.

Choudhari, S. M., \& Ananthanarayan, L. (2007). Enzyme aided extraction of lycopene from tomato tissues. Food Chemistry, 102(1), 77-81. http://dx.doi.org/10.1016/j.foodchem.2006.04.031.

Cuq, B., Rondet, E., \& Abecassis, J. (2011). Food powders engineering, between knowhow and science: constraints, stakes and opportunities. Powder Technology, 208(2), 244-251. http://dx.doi.org/10.1016/j. powtec.2010.08.012. 
Durigon, A., Parisotto, E. I. B., Carciofi, B. A. M., \& Laurindo, J. B. (2017). Heat transfer and drying kinetics of tomato pulp processed by cast-tape drying. Drying Technology, 3937, 1-9.

Durigon, A., Souza, P. G., Carciofi, B. A. M., \& Laurindo, J. B. (2016). Cast-tape drying of tomato juice for the production of powdered tomato. Food and Bioproducts Processing, 100, 145-155. http://dx.doi. org/10.1016/j.fbp.2016.06.019.

Ferreira, J. E. M., \& Rodriguez-Amaya, D. B. (2008). Degradation of lycopene and beta-carotene in model systems and in lyophilized guava during ambient storage: kinetics, structure, and matrix effects. Journal of Food Science, 73(8), C589-C594. http://dx.doi. org/10.1111/j.1750-3841.2008.00919.x. PMid:19019101.

Frabetti, A. C. C., Durigon, A., \& Laurindo, J. B. (2018). Effect of process variables on the drying of guava pulp by cast-tape drying. Lebensmittel-Wissenschaft + Technologie, 96, 620-626. http://dx.doi. org/10.1016/j.lwt.2018.06.021.

Kubola, J., Siriamornpun, S., \& Meeso, N. (2011). Phytochemicals, vitamin $\mathrm{C}$ and sugar content of Thai wild fruits. Food Chemistry, 126(3), 972-981. http://dx.doi.org/10.1016/j.foodchem.2010.11.104.

Kurozawa, L. E., Hubinger, M. D., \& Park, K. J. (2012). Glass transition phenomenon on shrinkage of papaya during convective drying. Journal of Food Engineering, 108(1), 43-50. http://dx.doi.org/10.1016/j. jfoodeng.2011.07.033.

Labuza, T. P. (1980). The effect of water activity on reaction kinetics of food deterioration. Food Technology, 34(59), 36-41.

Lannes, S. C. S., \& Medeiros, M. L. (2003). Processamento de achocolatado de cupuaçu por spray-dryer. Revista Brasileira de Ciências Farmacêuticas, 39(1), 115-123. http://dx.doi.org/10.1590/ S1516-93322003000100012.

López-Córdoba, A., \& Goyanes, S. (2017). Food oowder properties. In G. W. Smithers (Ed.), Reference module in food science (pp. 1-7). Amsterdam: Elsevier. http://dx.doi.org/10.1016/B978-0-08-1005965.21198-0

Mahendran, T. (2010). Physico-chemical properties and sensory characteristics of dehydrated guava concentrate: effect of drying method and maltodextrin concentration. Tropical Agricultural Research and Extention, 2(13), 48-54.

Naczk, M., \& Shahidi, F. (2004). Extraction and analysis of phenolics in food. Journal of Chromatography. A, 1054(1-2), 95-111. http:// dx.doi.org/10.1016/S0021-9673(04)01409-8. PMid:15553136.

Nindo, C. I., Powers, J. R., \& Tang, J. (2007). Influence of Refractance Window evaporation on quality of juices from small fruits. Lebensmittel-Wissenschaft + Technologie, 40(6), 1000-1007. http:// dx.doi.org/10.1016/j.lwt.2006.07.006.

Nunes, J. C., Lago, M. G., Castelo-Branco, V. N., Oliveira, F. R., Torres, A. G., Perrone, D., \& Monteiro, M. (2016). Effect of drying method on volatile compounds, phenolic profile and antioxidant capacity of guava powders. Food Chemistry, 197(Part A), 881-890. http://dx.doi. org/10.1016/j.foodchem.2015.11.050. PMid:26617030.

Ochoa-Martínez, C. I., Quintero, P. T., Ayala, A. A., \& Ortiz, M. J. (2012). Drying characteristics of mango slices using the Refractance Window $^{\mathrm{TM}}$ technique. Journal of Food Engineering, 109(1), 69-75. http://dx.doi.org/10.1016/j.jfoodeng.2011.09.032.

Ocoró-Zamora, M. U., \& Ayala-Aponte, A. (2013). Influence of thickness on the drying of papaya puree (carica papaya 1.) through refractance windowtm technology. Dyna, 80(182), 147-154.

Padula, M., \& Rodriguez-Amaya, D. B. (1986). Characterisation of the carotenoids and assessment of the vitamin a value of Brasilian guavas (Psidium guajava L.). Food Chemistry, 20(1), 11-19. http:// dx.doi.org/10.1016/0308-8146(86)90163-9.
Pavan, M. A., Schmidt, S. J., \& Feng, H. (2012). Water sorption behavior and thermal analysis of freeze-dried, Refractance Window-dried and hot-air dried açaí (Euterpe oleracea Martius) juice. LebensmittelWissenschaft + Technologie, 48(1), 75-81. http://dx.doi.org/10.1016/j. lwt.2012.02.024.

Pereira, C. G., \& Meireles, M. A. A. (2010). Supercritical fluid extraction of bioactive compounds: fundamentals, applications and economic perspectives. Food and Bioprocess Technology, 3(3), 340-372. http:// dx.doi.org/10.1007/s11947-009-0263-2.

Rahman, M. S. (2007). Handbook of food preservation (2nd ed.). Boca Raton: CRC Press. http://dx.doi.org/10.1201/9781420017373

Re, R., Pellegrini, N., Proteggente, A., Pannala, A., Yang, M., \& RiceEvans, C. (1999). Antioxidant activity appliying an improved ABTS radical cation decolorization assay. Free Radical Biology \& Medicine, 26(9-10), 1231-1237. http://dx.doi.org/10.1016/S08915849(98)00315-3. PMid:10381194.

Rodriguez-Amaya, D. B. (2001). A guide to carotenoid analysis in foods. Washington, D.C.: ILSI Press.

Silva, L. M. R., Figueiredo, E. A. T., Ricardo, N. M. P. S., Vieira, I. G. P., Figueiredo, R. W., Brasil, I. M., \& Gomes, C. L. (2014). Quantification of bioactive compounds in pulps and by-products of tropical fruits from Brazil. Food Chemistry, 143, 398-404. http://dx.doi.org/10.1016/j. foodchem.2013.08.001. PMid:24054258.

Silva, W. B., Silva, G. M. C., Santana, D. B., Salvador, A. R., Medeiros, D. B., Belghith, I., Silva, N. M., Cordeiro, M. H. M., \& Misobutsi, G. P. (2018). Chitosan delays ripening and ROS production in guava (Psidium guajava L.) fruit. Food Chemistry, 242, 232-238. http:// dx.doi.org/10.1016/j.foodchem.2017.09.052. PMid:29037684.

Singleton, V. L., Orthofer, R., \& Lamuela-Raventós, R. M. (1999). Analysis of total phenols and other oxidation substrates and antioxidants by means of Folin-Ciocalteu reagent. Methods in Enzymology, 299, 152-178.

Tonon, R. V., Brabet, C., \& Hubinger, M. D. (2009). Influência da temperatura do ar de secagem e da concentração de agente carreador sobre as propriedades físico-químicas do suco de açaí em pó. Food Science and Technology, 29(2), 444-450. http://dx.doi.org/10.1590/ S0101-20612009000200034.

U.S. Department of Agriculture - USDA. (2015). Agricultural research service, nutrient data laboratory: USDA National Nutrient Database for standard reference, release 28. Retrieved from https://ndb.nal. usda.gov/ndb/nutrients/

Verma, M., Singh, J., Kaur, D., Mishra, V., \& Rai, G. K. (2015). Effect of various dehydration methods and storage on physicochemical properties of guava powder. Journal of Food Science and Technology, 52(1), 528-534. http://dx.doi.org/10.1007/s13197-013-1020-0.

Zhang, M., Tang, J., Mujumdar, A. S., \& Wang, S. (2006). Trends in microwave-related drying of fruits and vegetables. Trends in Food Science \& Technology, 17(10), 524-534. http://dx.doi.org/10.1016/j. tifs.2006.04.011.

Zhong, Y., \& Shahidi, F. (2015). Methods for the assessment of antioxidant activity in foods. In F. Shahidi (Ed.), Handbook of antioxidants for food preservation (pp. 287-333). Cambridge: Elsevier.

Zotarelli, M. F., Carciofi, B. A. M., \& Laurindo, J. B. (2015). Effect of process variables on the drying rate of mango pulp by Refractance Window. Food Research International, 69, 410-417. http://dx.doi. org/10.1016/j.foodres.2015.01.013.

Zotarelli, M. F., da Silva, V. M., Durigon, A., Hubinger, M. D., \& Laurindo, J. B. (2017). Production of mango powder by spray drying and cast-tape drying. Powder Technology, 305, 447-454. http://dx.doi. org/10.1016/j.powtec.2016.10.027. 